\title{
Square Roots in Vedic Mathematics
}

\author{
Krishna Kanta Parajuli \\ Nepal Sanskrit University \\ Email:kkmparajuli@gmail.com
}

\begin{abstract}
This paper specially concentrates on finding the square roots of perfect as well as imperfect square numbers by the Vedic sutra Vilokanam. Generally, extracting the square root of a number is considered a tedious job. There are two methods taught in our present- day classroom by conventional approach to find square roots, which are lengthy and time consuming. But, the Vedic Sutra Vilokanam helps us to find square root of such numbers with a little practice. The technique mentioned for extracting square root for imperfect square numbers does not belong solely to Vedic Mathematics written by Swami Bharati Krishna Tirthaji Maharaja. Mathematicians have been using it as a part of their general practice. However, the technique for calculating square roots and described in Vedic Mathematics is difficult. The methods discussed and organization of the content of the paper here are intended to show the Vedic Mathematics as an extremely refined and efficient mathematical system than conventional system.
\end{abstract}

Key words: Square roots, Vedic sutra, perfect and imperfect square, Vilokanam, Navasesh

\section{Introduction}

\section{Vedic Mathematics}

Vedic Mathematics is the name given to the ancient system of mathematics which is a precise unique technique of calculations based on 16 sutras and 13 sub-sutras with simple rules and principles. Jagadguru Swami Sri Bharati Krishna Tirthaji ${ }^{[1]}$ rediscovered and developed methods and techniques for amplifying the principles contained in the aphorisms and their corollaries with encapsulating in modern form early last century between 1911 and 1918 is called Vedic Mathematics. It provides an innovative way of computations of almost all the mathematical problems, with which any mathematical problem be it arithmetic, algebra, geometry can be solved. The beauty of Vedic mathematics lies in the fact that it reduces otherwise cumbersome looking calculations in conventional mathematics to very simple ones.

[1] Tirthaji, B. K.(2015), Vedic Mathematics, pp- xxv, Motilal Vanarasidas, New Delhi, India. 


\section{Sixteen Sutras ${ }^{[2]}$}

\begin{tabular}{|c|c|}
\hline 1. एकाधिकेनपूर्वेण (Ekāddhikena Pūrevņa) & 9. चलनकलनाभ्याम् (Calana-Kalanābhyām) \\
\hline $\begin{array}{l}\text { 2. निखिलं नवतश्चरमंदशत: (Nikhilam Navataścara1 } \\
\text { Deśatah) }\end{array}$ & 10. यावदूनम् (Yāvadūnam) \\
\hline 3. ऊर्धव्वतर्यगभ्याम् (Ordhva-tiryabghyām) & 11. व्यष्टिसमष्टि: (Vyaşţtisamaşţih) \\
\hline 4. परा वर्त्यं योजयेत् (Parāvartya Yojayet) & 12. शेषाण्यड्केन चरमेण (Śeşāṇyańikena Carameņa) \\
\hline 5. शून्यं साम्यसमुच्चये (Śunyam Sāmyasamuccaye) & $\begin{array}{l}\text { 13. सोपान्त्यदूयमन्त्यम् } \\
\text { (Sopāntyadvayamantyam) }\end{array}$ \\
\hline 6. आनुरूप्ये शून्यमन्यत् (Ånurūpye) Śñnyarmanyat) & 14. एकन्यूनेनपूर्वेण (Ekanyūņena Pūrveņa) \\
\hline 7. संकलनव्यवकलनाभ्याम्(Sańkalana-vyavakalanāb & 15. गुणितसमुच्चय: (Gunitasamuccayah) \\
\hline (Pūraņāpū & 16. गुणकसमुच्चय: (Guņak \\
\hline
\end{tabular}

\section{Thirteen Sub-Sutras}

\begin{tabular}{|c|c|}
\hline 1. आनुरूप्येण (Anurūpyena) & 8. अन्त्ययोर्दशकेकपि (Antyayordasaképi) \\
\hline 2. शिष्यते शेषसंज्ञ: (Śişyate Ś Şşasaņjńah) & 9. अन्त्ययोरेव (Antyayoreva) \\
\hline $\begin{array}{l}\text { 3. आद्यमाद्ये नान्त्यमन्त्येन (Ādyamādye nāntya- } \\
\text { mantyena) }\end{array}$ & 10. समुच्चयगुणित: (Samuccayagunitah) \\
\hline 4. केवलै: सप्तकं गुण्यात् (Kevalaih Saptakam Guṇyāt) & 11. लोपस्थापनाभ्याम् (Lopanasthāpanābhyām) \\
\hline 5. वेष्टनम् (Veşţanam) & 12. विलोकनम् (Vilokanam) \\
\hline 6. यावदूनं तावदूनम् (Yāvadūnam Tāvadūmam) & $\begin{array}{l}\text { 13. गुणितसमुच्चय: समुच्चयगुणित: } \\
\text { (Gunitasamuccayah Samuccayagunitah) }\end{array}$ \\
\hline $\begin{array}{l}\text { 7. यावदूनं तावदूनीकृत्य वर्गं च योजयेत् (Yāvadunam } \\
\text { Tāvadnikrtya Vargańca Yajayet) }\end{array}$ & \\
\hline
\end{tabular}

Square Roots: To understand square roots, it will be important to understand what is square. In arithmetic or algebra, square is the result of multiplying a quantity of itself. In Geometry, a quadrilateral with equal sides and equal angles is a square. Square root of a number is a number which when multiplied by itself, gives the given number. If $x$ is a number, then its square root is $\sqrt{x}$, where $\sqrt{ }$ is radical sign and it indicates the square root of given number. Thus, if we multiply a number by itself, we get the square of that number. The number itself is called the square root of the product. Generally, extracting the square root of a number is considered a tedious job. There are two methods taught in our present-day classroom by conventional to find square roots, i.e. (i) method of factors and (ii) method of division. Both the methods are lengthy and time consuming by conventional approach. But, the Vedic Sutra

${ }^{[2]}$ Tirthaji, B. K.(2015), Vedic Mathematics, pp (xvii- xviii), Motilal Vanarasidas, New Delhi, India. 
help us the calculate square roots of any given number - perfect as well as imperfect. Before we move to Vedic technique to find the square root of a number, we should know the following fundamental rule:

(i) Every perfect square ends either of the numbers: $0,1,4,5,6$ or 9 .

(ii) A number is not a perfect square if it is end with 2, 3, 7, or 8 .

(iii) If the given number is of $\mathrm{n}$ digits then its square roots of it will be of $\frac{n}{2}$ digits if $\mathrm{n}$ is of even or $\frac{n+1}{2}$ digits if $\mathrm{n}$ is of odd.

i.e. Alternatively, if the square root contains $n$ digits, the square must consist of $2 n$ or $(2 n-1)$ digits. Let us find a relation table between square and square roots of $1^{\text {st }} 20$ natural numbers.

Table No. 1

\begin{tabular}{|c|c|c|}
\hline Natural Number (N) & $\mathbf{N}^{\mathbf{2}}$ & Last Digit of $\mathbf{N}^{\mathbf{2}}$ \\
\hline 1 & 1 & 1 \\
2 & 4 & 4 \\
3 & 9 & 9 \\
4 & 16 & 6 \\
5 & 25 & 5 \\
6 & 36 & 6 \\
7 & 49 & 9 \\
8 & 64 & 4 \\
9 & 81 & 1 \\
\hline 10 & 100 & 0 \\
\hline 11 & 121 & 1 \\
12 & 144 & 4 \\
13 & 169 & 9 \\
14 & 196 & 6 \\
15 & 225 & 5 \\
16 & 256 & 6 \\
17 & 289 & 9 \\
18 & 324 & 4 \\
19 & 361 & 1 \\
\hline 20 & 400 & 0 \\
\hline
\end{tabular}


From the above table, it can be concluded that:

(i) A perfect square can never have 2,3,7 or 8 at its unit place.

(ii) A square ending in 1 must have 1 or 9 as the last digit of the square root. A square ending in 4 must have 2 or 8 as the last digit of the square root. A square ending in 6 must have 4 or 6 as the last digit of the square root. A square ending in 5 must have 5 as the last digit of the square root. A square ending in 9 must have 3 or 7 as the last digit of the square root. A square ending in 0 must have 0 as the last digit of the square root.

(iii) A number cannot be a perfect square in the following circumstances: ${ }^{[3]}$

- if it ends in2, 3, 7 or 8 ;

- if it terminates in an odd number of zeros;

- if its last digit is 6 but its penultimate (2nd last) digit is even;

- if its last digit is not 6 but its penultimate (2nd last) digit is odd;

- if, even though the number be even, its last two digits (taken together) are not divisible by 4 .

A part from the above table, let us look at the following nearest square root table that will help us to find the square root of a number instantly.

Table No. 2

\begin{tabular}{|l|c|c|c|c|c|c|c|c|c|}
\hline Numbers & $\begin{array}{c}1- \\
3\end{array}$ & $4-8$ & $9-15$ & $\begin{array}{c}16- \\
24\end{array}$ & $\begin{array}{c}25- \\
35\end{array}$ & $\begin{array}{c}36- \\
48\end{array}$ & $\begin{array}{c}49- \\
63\end{array}$ & $\begin{array}{c}64- \\
80\end{array}$ & $\begin{array}{c}81- \\
99\end{array}$ \\
\hline $\begin{array}{l}\text { Nearest greatest } \\
\text { integer of square } \\
\text { roots }\end{array}$ & 1 & 2 & 3 & 4 & 5 & 6 & 7 & 8 & 9 \\
\hline
\end{tabular}

In Vedic Mathematics, there are two methods to extract square roots of the numbers.

(i) Vilokanam (By mere observation $)^{[4]}$

(ii) Dwandawayogah (Duplex combination)

The article concentrates only on Vilokanam rule between them. There are 16 Sutras and 13

[3] Tirthji, B. K. (2015). Vedic Mathematics: $17^{\text {th }}$ revised edition, pp (295-300): Motilal Banarasidass, New Delhi.

[4] Tirthji, B. K. (2015). Vedic Mathematics: $17^{\text {th }}$ revised edition, pp (295-300): Motilal Banarasidass, New Delhi. 
Sub-sutras in Vedic Mathematics, out of them Vilokanam is one of the sub-sutras. The meaning of Vilokanam in Vedic Mathematics is "by mere observation". Before finding the square root by Vilokanam method, it is better to study the method case wise:

\section{Case (a): Exact square root of 3-4 digits. ${ }^{[5]}$}

\section{Rule:}

- Make a group of two starting from the right.

- Look at the unit digit of the number and observe your answer in table 1, which help us to decide the digit at the unit place.

- Move to second group and find the ten's digit of square root.

Example: Find the square root of 2209.

\section{Solution}

$\frac{22}{2^{\text {nd }} \text { group }} \quad \frac{09}{1^{\text {st }} \text { group }}$

- Here unit digit of $1^{\text {st }}$ group is 9, so its square root ends with 1 or 3 .

- Here, in second group, $16<22<25$. So, digit at the ten's place is 4 .

- We have two options: $\sqrt{2209}=41$ or 43

- If $4 \times(4+1)$ is less than 22 i.e. 22 is greater than 20 , so take the greater number i.e. 43.

\section{Case (b): Exact square root of 5 - 6 digits. $^{[4]}$}

\section{Rule:}

- Make a group of two digits starting from the right. Here, we will have three groups. Denote the left digit by $\mathrm{L}$, the middle digit by $\mathrm{M}$ and the right digit by $\mathrm{R}$.

- The first (L) and third (R) group will give us the hundred's place digit and unit place digit. These two can be written only through observation, with the help of table (1) and table (2).

- Subtract $\mathrm{L}^{2}$ from the first pair and carry down the next digit from the dividend.

- Compare the new dividend by 2LM. Put different value of M in 2LM and select the best possible digit. So that $2 \mathrm{LM} \leq$ new dividend.

[5] Bathia, D.(2010). Vedic Mathematics Made Easy; pp(66-76)\& (157-169); Jaico Publishing House, Mumbai, India 
- In order to avoid confusion over the choice of the number, use the Navaseshrule.

- $\quad$ Exact square root $=$ LMR

Example: Find the square root of 692224.

Solution: Make a group of two digits, starting from right.

$$
\frac{69}{\mathrm{~L}} \quad \frac{22}{\mathrm{M}} \quad \frac{24}{\mathrm{R}}
$$

- Since the unit digit of the given number ends with 4 , therefore the square root ends in 2 or 8 .

- 69 is the left group lies between $8^{2}<69<9^{2}$, hence, $\mathrm{L}=8$.

- Now subtract $\mathrm{L}^{2}$ from the given number and carry down the next digit from the dividend as shown here:

$$
\begin{aligned}
& 6 \\
& -8^{2}
\end{aligned}
$$

- Compare the new dividend by $2 \mathrm{LM}=2 \times 8 \times \mathrm{M}=16 \mathrm{M}$

Put different values of $\mathrm{M}$

For $\mathrm{M}=3,16 \times 3=48<52$

For $\mathrm{M}=4,16 \times 4>52$, hence, $\mathrm{M}=3$.

Now we are left with two options;

$\sqrt{692224}=832$ or 838

- Apply the Navasesh ${ }^{[6]}$ method to overcome the confusion in selecting the correct answer.

\begin{tabular}{|l|l|l|}
\hline Digit sum of 692224 & Digit sum of $(832)^{2}$ & Digit sum of $(838)^{2}$ \\
\hline $6+9+2+2+2+4=7$ & $(8+3+2)^{2}=4^{2}=1+6=7$ & $(8+3+8)^{2}=1^{2}=1$ \\
\hline
\end{tabular}

Hence, $\sqrt{692224}=832$.

Note: LMR is just a symbolic number of square roots. $\mathrm{L}$ is the $100^{\text {th }}$ place value number, similarly $\mathrm{M}$ is $10^{\text {th }}$ place value number and $\mathrm{R}$ is unit place value number of the required square roots.

[6] Singhal, V. (2014); Vedic Mathematics for all ages, pp-139; Motilal Banarasidass; New Delhi 


\section{Square Roots of Imperfect Squares by Vilokanam Rule:}

The technique to find square root of perfect square as mentioned in the first part of the article is very simple. However, the technique to find square roots of imperfect square is slightly difficult as compared to perfect square. We will be able to find the square root of imperfect squares (i.e. irrational numbers) by Vilokanam rule and with a little practice. By this method, we find the square root of irrational numbers by using the formula as:

Square root of irrational number $=\sqrt{\text { nearest perfect square }}+\frac{\text { Deviation from irrational number }}{2 \times \sqrt{\text { nearest perfect square }}}$

\section{Example: Find the square root of 204.}

Solution: perfect squares approaching 204 is 196.

Deviation $=204-196=8$

$$
\therefore \sqrt{204}=\sqrt{196}+\frac{8}{2 \times \sqrt{196}}=14+\frac{8}{28}=14.285
$$

\section{Examples: Find the square root of 474.}

Solution: Perfect square approaching 474 is 484 .

Deviation $=474-484=-10$

$$
\therefore \sqrt{474}=\sqrt{484}-\frac{10}{2 \times \sqrt{484}}=22-\frac{5}{22}=22-0.227=21.773
$$

Findings: The conventional method of extracting square root for perfect square as well as imperfect square root is possible only through long division or factor method and these methods are time consuming and error prone in these cases, but the Vedic method Vilokanam help us to find square root of such numbers with a little practice.

\section{Conclusion}

i) It should be divided the extracting the square roots in two parts specific and general i.e. for perfect square and imperfect square numbers. Because, the technique of general squares is slightly difficult as compared to the technique of perfect square.

ii) The technique mentioned for extracting square root for imperfect square numbers isn't completely mentioned in Vedic Mathematics written by Bharati Krishna Tirthaji. For this, mathematician can use Vilokanam as a part of their practice.

iii) Finding square roots is also useful in Geometry while dealing with the area, perimeter, etc of geometric figures. The concepts of this topic will also be useful in dealing with the applications of the theorem of Pythagoras.

iv) It is advisable to memorize the table of square and square roots of certain level of numbers to operate further level of numbers. 


\section{References}

Bathia,D. (2010). Vedic Mathematics Made Easy, Jaico Publishing House: Mumbai, Bangalore.

Bose, S. (2014). Vedic Mathematics: V \& S Publishers, Delhi.

Chauthaiwala, M., Kolluru, R. (2010). Enjoy Vedic Mathematics: Sri Sri Publications Trust, Art of Living International Centre, Bangalore - 560082.

Cutler, A. \& Rudolph M.The Trachtenberg Speed System of Basic Mathematics (English edition),Asia Publishing House, New Delhi, 2008

Glover, J. T. (2002). Vedic Mathematics for schools: Motilal Banarasidass Publishers Pvt.Ltd.

Gupta, A. (2006). The power of Vedic Mathematics: Jaico Publishing House 121 Mahatma Gandhi Road, Mumbai-400 001.

Kapoor, S.K., Kapoor, R. P. (2010). Practice Vedic Mathematics (skills for perfection of intelligence) : Lotus Press, Daryaganj, New Delhi-02.

Kumar, A. (2010). Vedic Mathematics Sutra:UpkarPrakasan, Agra-2.

Singhal, V. (2014). Vedic Mathematics for all ages: Motilal Banarasidass Publishers Pvt. Ltd., Delhi.

TirthajiB. K. (2009). Vedic mathematics: Motilal Banarsidass Publishers Pvt.Ltd, Delhi. Tirthaji, B. K. (1965).Vedic Mathematics:Motilal Banarasidass, New Delhi, India. 